DOI

\title{
ОСОБЛИВОСТІ СТРУКТУРНОЇ ПЕРЕБУДОВИ ВЕНОЗНОГО РУСЛА ПЕРЕДСЕРДЬ ПРИ АРТЕРІАЛЬНІЙ ГІПЕРТЕНЗІЇ У МАЛОМУ КОЛІ КРОВООБІГУ
}

\section{Свно Б. Слабий, М. С. Гнатюк \\ ДВНЗ «Тернопільський державний медичний університет імені І. Я. Горбачевського МОз України»}

\begin{abstract}
РЕЗЮМЕ. Змодельована пострезекційна легенева артеріальна гіпертензія призводить до розвитку легеневого серця та вираженої структурної перебудови венозного русла передсердь. Остання характеризується суттєвим розширенням, повнокров'ям, деформацією просвіту венозних структур лівого та правого передсердь, порушенням їх дренажної функції, що посилює гіпоксію та деструктивні процеси у міокарді, які домінують у правому передсерді декомпенсованого легеневого серця.

КЛЮчОВІ СЛОВА: венозне русло, передсердя, пострезекційна легенева артеріальна гіпертензія.
\end{abstract}

Вступ. Легенева гіпертензія нерідко зустрічається в клінічній практиці та ускладнюється переважно гіперфункцією та гіпертрофією правого шлуночка, тобто розвитком легеневого серця $[1,2]$. Сьогодні дослідники вказують, що хронічне легеневе серце характеризується гіпертрофією, дилатацією і дисфункцією м'яза правого шлуночка, що викликано ураженням легеневої паренхіми i/або легеневого судинного русла між місцем відходження стовбура легеневої артерії і місцем впадання легеневих вен у ліве передсердя. На сьогодні легеневе серце набуває все більшого значення у зв'язку із значним ростом хронічних обструктивних захворювань легень, хронічних форм туберкульозу, професійних ушкоджень легень, при яких основною причиною втрати працездатності та летальності $\epsilon$ легеневе серце. Патогенез останнього складний і досить багатогранний, що значною мірою ускладнює адекватну, своєчасну діагностику легеневої гіпертензії та легеневого серця [3]. Варто вказати, що до сьогоднішнього дня дискусійними залишаються питання про поширеність гіпертрофії правого шлуночка при хронічних ураженнях легеневої паренхіми, а також відносно ролі легеневої гіпертензії в патогенезі легеневого серця $[2,3]$, а венозне русло передсердь при даній патології досліджено недостатньо.

Метою дослідження було вивчення особливостей структурної перебудови венозного русла передсердь при пострезекційній легеневій артеріальній гіпертензії.

Матеріал і методи досліджень. Комплексом морфологічних методів досліджені вени передсердь 19 статевозрілих свиней-самців в'єтнамської породи, які були поділені на 3-и групи. 1-а група нараховувала 6 інтактних дослідних тварин, 2-а - 8 свиней з артеріальною легеневою гіпертензією та компенсованим легеневим серцем, 3-я - 5 тварин з артеріальною легеневою гіпертензією та декомпенсацією легеневого серця.
Останнє підтверджувалося наявністю у дослідних тварин задишки, синюшності слизових оболонок, гідротораксу, гідроперикарду, застійних явищ в органах великого кола кровообігу. Пострезекційну легеневу артеріальну гіпертензію і легеневе серце моделювали шляхом виконання у щурів правосторонньої пульмонектомії [4]. Оперативні втручання виконували в умовах тіопенталового наркозу з дотриманням правил асептики та антисептики. Через місяць від початку досліду здійснювали евтаназію свиней кровопусканням в умовах тіопенталового наркозу. Серце розрізали за методикою Г. Г. Автанділова, проводили окреме зважування камер серця, їх планіметрію [5]. 3 частин серцевого м'яза також вирізали шматочки, які фіксували в 10 \% розчині формаліну, проводили через етилові спирти зростаючої концентрації та поміщали у парафін. Мікротомні зрізи після депарафінізації забарвлювали гематоксиліномеозином, за методом ван-Гізон, Маллорі, Гейденгайна, Вейгерта [6].

Результати й обговорення. Окремим зважуванням частин серця та їх планіметрією встановлено, що через місяць після правосторонньої пульмонектомії виникла гіпертрофія камер серця та їх розширення з домінуванням маси правого шлуночка та його дилатації, тобто легеневе серце $[4,7]$. Відомо, що вени серцевого м'яза починаються із венозної ланки гемомікроциркуляторного русла (посткапілярів та венул). Внутрішньоорганні вени неушкодженого серцевого м'яза свиней за структурою суттєво відрізнялися від вінцевих артерій. У досліджуваних венах міокарда межі між внутрішнім, середнім та зовнішнім шарами судинної стінки були нечіткими. Структурно стінка посткапілярних венул представлена ендотелієм на базальній мембрані. Крім ендотеліоцитів та базальної мембрани у стінці досліджуваної венозної структури локалізувалися також гладком'язові клітини, еластичні та колагенові волокна. Варто зазначити, що зав- 
Огляди літератури, оригінальні дослідження, погляд на проблему

дяки названим зовнішнім морфологічним утворенням міокардіальні вени не беруть участі в обмінних процесах.

Зустрічалися також найменші серцеві вени (Тебезія), які починаються у міокарді та впадають переважно у праве передсердя. Спостерігалася варіабельність локалізацій гладких м'язових клітин у венозних стінках. У деяких венах вказані клітини не зустрічалися, а в інших - розміщувалися в один шар. У місцях злиття вен м'язові клітини нерідко локалізувалися у 2-3 шари.

Проведеними дослідженнями встановлено, що вже у пострезекційному компенсованому легеневому серці вени передсердь зазнавали вираженої структурної перебудови. У змодельованих патологічних умовах майже у всіх спостереженнях вени передсердь розширені, переповнені кров'ю. Наявний виражений перивазальний набряк місцями здавлював вени, звужував їх просвіт та деформував досліджувані судини. Аналогічна деформація вен передсердь спостерігалася при перивазальному склерозі, який нерідко зустрічався при змодельованій патології у передсердях. У венозних стінках виявлялася дистрофія м'язових клітин, стромальних структур, ендотеліоцитів та десквамація останніх місцями. Деякі ендотеліоцити та гладкі міоцити були з явищами вираженого набряку, межі між вказаними структурами нечіткі (рис. 1, 2). Відмічалися також клітини, збільшені у розмірах, дистрофічно змінені.

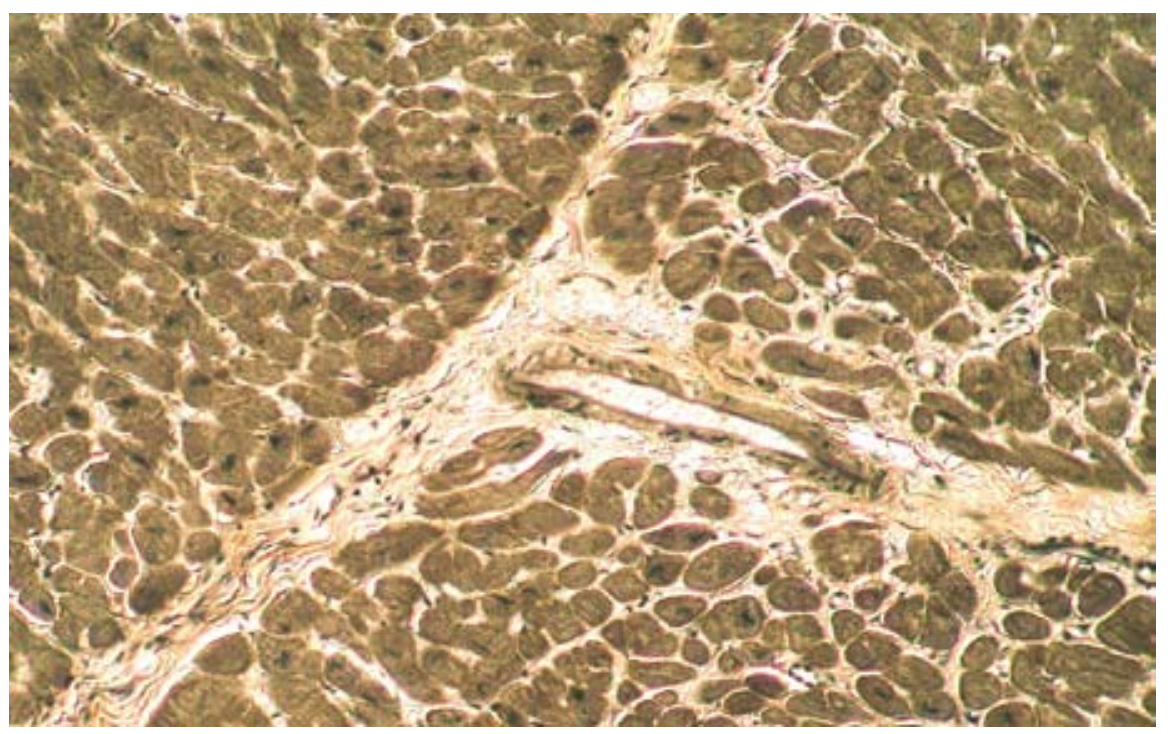

Рис. 1. Деформований просвіт вени, дистрофічні зміни міоцитів, ендотеліоцитів, виражені перивазальний набряк і склероз, осередки дистрофії кардіоміоцитів у лівому передсерді компенсованого легеневого серця. Забарвлення за ван-Гізон. 36.: х 125.

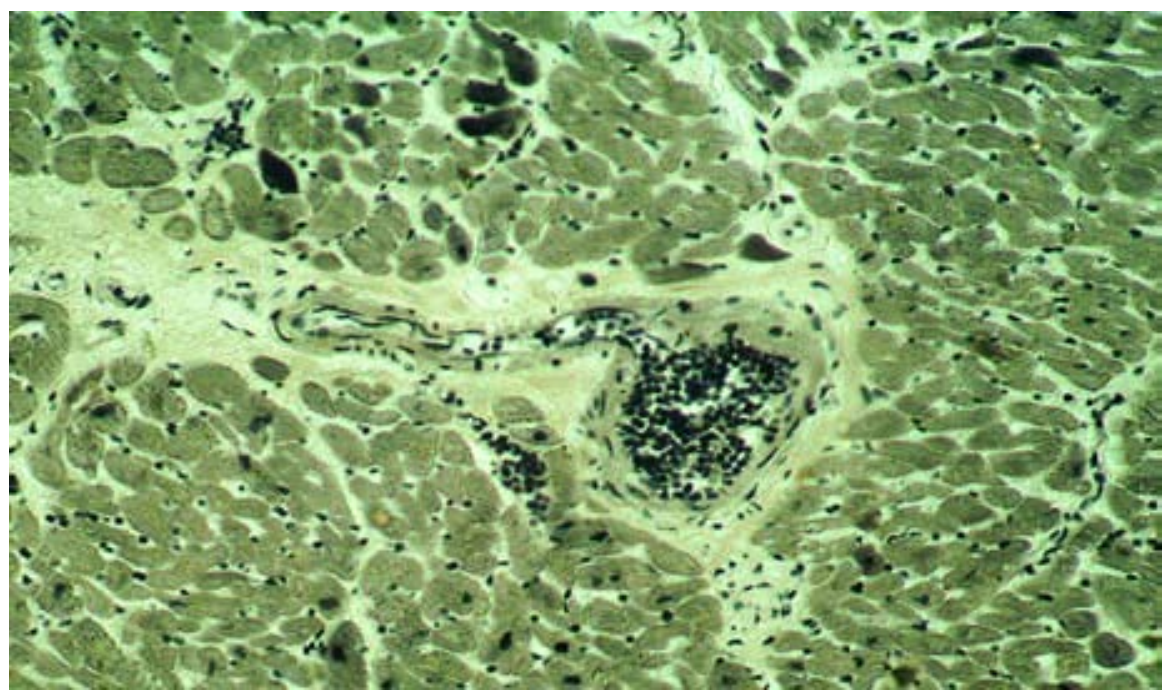

Рис. 2. Розширена та повнокровна вена з явищами стазу, виражений перивазальний набряк і склероз, осередки дистрофії, некробіозу окремих кардіоміоцитів у стінці правого передсердя компенсованого легеневого серця. Забарвлення за Гейденгайном. 36.: х 125. 
Огляди літератури, оригінальні дослідження, погляд на проблему

При гістологічному дослідженні мікропрепаратів передсердь експериментальнихтварин після правосторонньої пульмонектомії спостерігали виражені судинні розлади (повнокров'я переважно венозних судин мікрогемоциркуляторного русла, стази, тромбози, діапедезні перивазальні крововиливи), стромальний та перивазальний набряк, дистрофічні зміни та некрози кардіоміоцитів, ендотеліоцитів, стромальних структур. Некрози кардіоміоцитів чітко виявлялися при забарвленні мікропрепаратів за Гейденгайном (рис. 2, 3). При світлооптичному дослідженні мікропрепаратів передсердь спостерігалися осередки м'язових волокон із зникненням поперечної посмугованості. Місцями у мікропрепаратах передсердь виявляли- ся гіпертрофовані кардіоміоцити із збільшеними розмірами ядер, відмічалося також розростання сполучної тканини. Місця некротизованих кардіоміоцитів заміщувалися сполучною тканиною, а інколи жировою. У деяких досліджуваних венах відмічалася проліферація ендотеліоцитів, які нерідко призводили до облітерації просвіту судин. Місцями стінки венозних судин передсердь потовщені, просвіт їх звужений, ендотеліоцити дистрофічно змінені, місцями десквамовані, перивазальні тканини з вираженим набряком та вогнищевими інфільтратами. У деяких венах відмічалася деструкція мембран, структурні зміни міоцитів у вигляді дистрофії та некробіозу. Виявлені патогістологічні зміни домінували у правому передсерді (рис. 4).

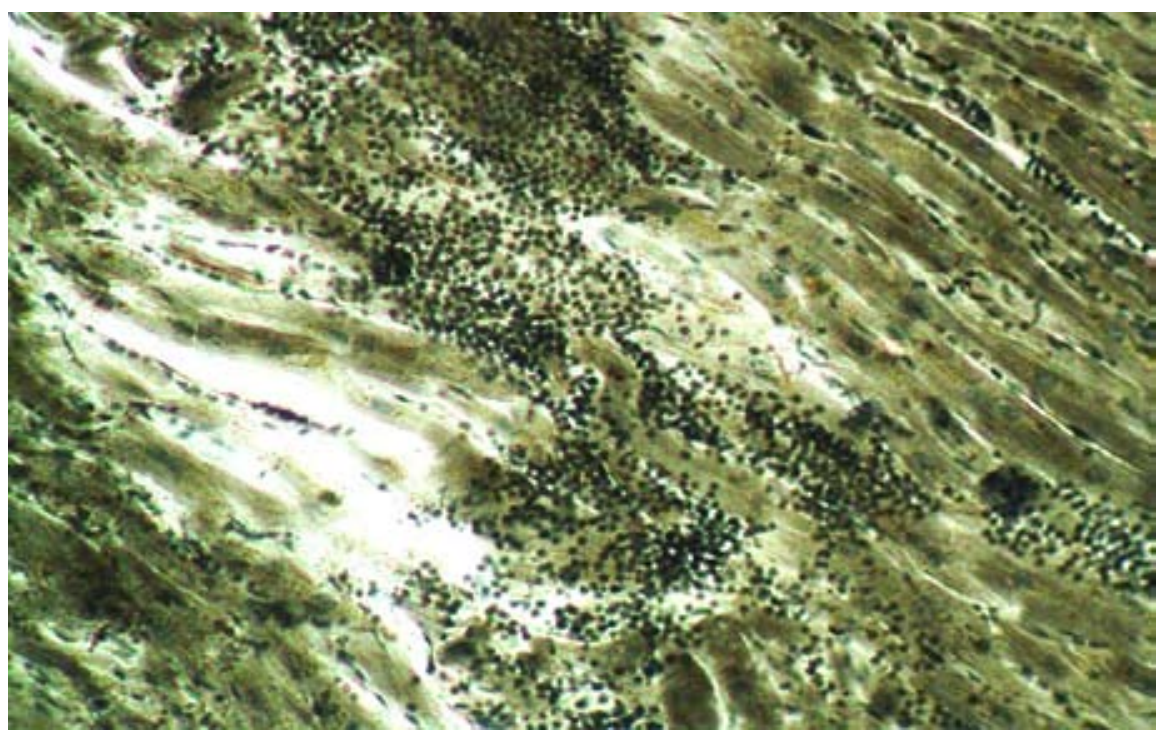

Рис. 3. Виражений стромальний набряк, осередки крововиливів, стази у мікросудинах, дистрофія кардіоміоцитів у правому передсерді декомпенсованого легеневого серця. Забарвлення за Гейденгайном. 36.: х 140.

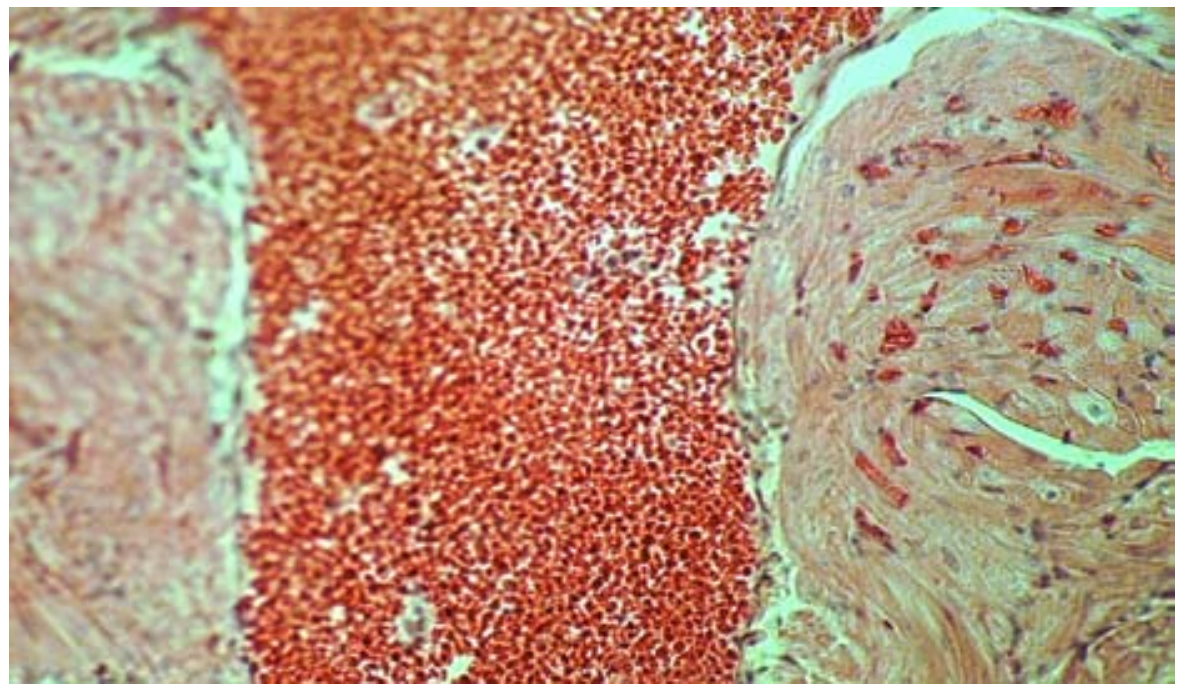

Рис. 4. Розширена, повнокровна найменша вена, дистрофія ендотеліоцитів, кардіоміоцитів, крововиливи у правому передсерді декомпенсованого легеневого серця. Забарвлення гематоксиліном-еозином. $36 .:$ x 160. 
Огляди літератури, оригінальні дослідження, погляд на проблему

В останні роки морфологи все більше уваги при різних патологічних станах звертають на стан ендотеліальних клітин. На сьогодні вважають, що вказані клітини $\epsilon$ активним ендокринним органом, котрий синтезує різні біологічно активні субстанції, необхідні для регуляції життєво важливих процесів у організмі (згортання крові, тонус та ремоделювання судин, функціональна активність нирок, скоротливість серця, дифузія води, іонів, продуктів метаболізму). Ендотеліоцити також виконують бар'єрну, гемостатичну, реологічну, продукуючу, метаболічну, транспортну та репаративну функції. Вони відіграють важливу роль у ремоделюванні судинної стінки, тобто у змінах її структури та функції в різних фізіологічних та патологічних умовах. Ендотеліальні клітини також синтезують оксид азоту (NO) - ендотеліальну субстанцію релаксації судин. Звідси випливає, що порушення структури значної кількості ендотеліоцитів призводить до їхньої дисфункції, блокади NO-синтази, зниження синтезу NO і активації процесів його деградації. Наведені явища супроводжуються спазмом та звуженням судин, що не лише підтримує, але й посилює гіпоксію, набряк, дистрофію та некробіотичні зміни в клітинах і тканинах з подальшою інфільтрацією та розвитком кардіосклерозу [8, 9].

Висновок. Тривала пострезекційна артеріальна легенева гіпертензія призводить до вираженої структурної перебудови венозного русла передсердь, яка характеризується розширенням судин, деформацією їхнього просвіту та ураженням ендотеліоцитів, ендотеліальною дисфункцією, погіршанням кровопостачання серцевого м'яза, гіпоксією, дистрофічними, некробіотичними змінами клітин і тканин, інфільтративними та склеротичними процесами. Виявлені патоморфологічні зміни домінували у правому передсерді та при декомпенсації легеневого серця.

Перспективи подальших досліджень. Детальне всесторонн $\epsilon$ вивчення цих явищ представляє перспективну проблему з метою їхнього врахування при діагностиці, корекції та профілактиці уражень міокарда при пострезекційній артеріальній легеневій гіпертензії.

\title{
ЛITЕРАТУРА
}

1. Норейко С. Б. Бронхообструктивный синдром у больных деструктивным туберкулезом легких / С. Б. Норейко // Вестник гигиены и эпидемиологии. - 2004. T. 8, №1. - С. 130-135.

2. Амосова К. М. Клінічний перебіг та стан міокарда з хронічним легеневим серцем унаслідок хронічної обструктивної патології легень залежно від наявності легеневої гіпертензії / К. М. Амосова, Л. Ф. Конопльова, І. Д. Мазур // Серце і судини. - 2009. - № 2. - С. 48-52.

3. Barnes P. Y. Chronic obstructive pulmonary disease molecular and cellular mechanisms / P. Y. Barnes, D. Shapiro, R. A. Pamwels // Eur. Respirat. J. - 2003. - Vol. 22. P. 672-678.

4. Гнатюк М. С. Морфометрична оцінка особливостей ремоделювання артерій шлуночків серця при пострезекційній артеріальній легеневій гіпертензії / М. С. Гнатюк, Л. В. Татарчук, О. Б. Слабий // Вісник проблем біології і медицини. - 2011. - вип. 2, Т. 2. - С. 57-60.

5. Автандилов Г. Г. Основы количественной патологической анатомии / Г. Г. Автандилов. - М. : Медицина, 2002. -268 c.

6. Сорочинников А. Г. Гистологическая и микроскопическая техника / А. Г. Сорочинников, А. Е. Доросевич. - М. : Медицина, 1997. - 448 с.

7. Трускавецький Б. Л. Зіставлення ехокардіографічних та рентгенологічного методів у діагностиці патологічних змін правого шлуночка / Б. Л. Трускавецький // Науковий вісник Ужгородського університету. Серія «Медицина». - 2011. - випуск 40. - С. 148-151.

8. Непомнящих Л. М. Морфогенез важнейших общепатологических процессов в серце / Л. М. Непомнящих. - Новосибирск : Наука, 2001. - 352 с.

9. Садовников В. А. Моделирование состояния дезинтеграции сердца предельными загрузками / В. А. Садовников, А. Н. Баранов // Морфология. - 1998. - Т. 113, № 3. - C. 104-106.

\section{PECULIARITIES OF STRUCTURAL RECONSTRUCTION OF VENOUS BED OF ATRIUM AT ARTERIAL HYPERTENSION IN SMALL BLOOD CIRCULATION}

\author{
○O. B. Slabyi, M. S. Hnatiuk \\ SHEI «Ternopil State Medical University by I. Ya. Horbachevsky of MPH of Ukraine»
}

SUMMARY. The peculiarities of remodeling veins of the atrium were studied by morphological methods of postresection pulmonary arterial hypertension. It was established that the model pathology results in widening, deformation, fool-blooded of the veins, damage endotheliocytes that led to their dysfunction, decreasing of organ blood supply, hypoxia, dystrophic and necrobiolic changes of tissues and cells, infiltration, sclerosis. Structural changes of veins prevail in right atrium of decompensated cor pulmonale.

KEY WORDS: venous bed, atrium, pulmonary arterial hypertension. 